\title{
THE EFFECT OF COLD SHOCK AND DEEP-FREEZING ON THE CONCENTRATION OF MAJOR CATIONS IN SPERMATOZOA
}

\author{
P. J. QUINN AND I. G. WHITE \\ Department of Veterinary Physiology, University of Sydney, Australia
}

(Received 5th October 1965)

\begin{abstract}
Summary. Cold-shocking and deep-freezing bull and ram semen caused an influx of sodium to and an efflux of potassium and magnesium from the spermatozoa. The movement of these cations was accentuated when the semen was diluted $1: 8$ in sodium phosphate buffers. Calcium is actively accumulated in the spermatozoa of these two species after cold-shocking.

No significant changes in the cation content of human, dog, rabbit or fowl spermatozoa were found after cold-shocking. There was no great disturbance of the cation status of human and fowl spermatozoa, even after deep-freezing.

Lecithin prevented calcium accumulation in bull and ram spermatozoa on cold-shocking, and glycerol also had this effect on cold-shocked bull spermatozoa. An egg-yolk-citrate/glycerol-fructose diluent protected bull and ram spermatozoa to a considerable extent from the influx of sodium and the efflux of potassium that occurs after deep-freezing to $-79^{\circ} \mathrm{C}$.
\end{abstract}

\section{INTRODUCTION}

Cold shock is the irreversible loss of viability occurring when the spermatozoa of some species, e.g. bull and ram, are quickly cooled to about $0^{\circ} \mathrm{C}$. The most obvious sign of cold shock is loss of motility which is not regained on warming the semen. There is also a decrease in the rate of fructose breakdown by the spermatozoa, a decrease in the oxygen uptake and a fall in ATP, which can now be no longer synthesized and used to supply energy for the maintenance of motility (Mann \& Lutwak-Mann, 1955). The proportion of cells staining with eosin or congo red (Lasley, Easley \& McKenzie, 1942; Hancock, 1951) increases and there is evidence that both high and low molecular weight substances are lost from the spermatozoa (Mann \& Lutwak-Mann, 1955; Blackshaw \& Salisbury, 1957), the cell surface of which tends to disintegrate (Walton, 1957). Cold shock can be largely prevented or decreased by adding egg yolk to semen and recent work indicates that the active principle is the phospholipid, lecithin (Kampschmidt, Mayer \& Herman, 1953; Blackshaw, 1954; Blackshaw \& Salisbury, 1957). 
Deep-freezing spermatozoa to the temperature of a dry ice-alcohol mixture $\left(-79^{\circ} \mathrm{C}\right)$ causes an even more severe drop in motility and metabolism (White, Blackshaw \& Emmens, 1954). However, by including glycerol in the medium (Polge, Smith \& Parkes, 1949; Smith \& Polge, 1950a, b) it is possible to revive a greater proportion of the spermatozoa, and a vast literature on this subject has now accumulated (see Emmens \& Blackshaw, 1956; Maule, 1962).

This paper is concerned with the effect of cold-shocking and deep-freezing on the concentration of the major cations in the spermatozoa of species (bull, ram, dog, man, rabbit and fowl) differing considerably in their susceptibility to cold shock. Studies of the protective action of lecithin and glycerol in relation to the movements of cations in and out of bull and ram spermatozoa are also presented.

\section{MATERIALS AND METHODS}

Semen was collected by methods described in an earlier paper (Quinn, White \& Wirrick, 1965). It was kept at 15 to $20^{\circ} \mathrm{C}$ during transfer to the laboratory and care was taken to prevent sudden changes in temperature. Only samples of good initial motility were used. The method for separating spermatozoa and seminal plasma and the technique for estimating sodium, potassium, calcium and magnesium in the spermatozoa, using the atomic absorption spectrophotometer, was the same as before (Quinn et al., 1965).

Isotonic buffers of $\mathrm{pH} 7$ had a composition of $0.048 \mathrm{M}-\mathrm{Na}_{2} \mathrm{HPO}_{4} \cdot \mathrm{H}_{2} \mathrm{O}$, $\mathrm{NaH}_{2} \mathrm{PO}_{4} \cdot \mathrm{H}_{2} \mathrm{O}$ and $0.040 \mathrm{M}-\mathrm{NaCl}$ for ram semen and $0.012 \mathrm{M}-\mathrm{Na}_{2} \mathrm{HPO}_{4} .12 \mathrm{H}_{2} \mathrm{O}$, $0.008 \mathrm{M}-\mathrm{NaH}_{2} \mathrm{PO}_{4} \cdot \mathrm{H}_{2} \mathrm{O}$ and $0.20 \mathrm{M}-\mathrm{NaCl}$ for bull semen. Fructose $(400 \mathrm{mg} /$ $100 \mathrm{ml}$ ) was added to each of the diluents as a substrate for the spermatozoa.

Lecithin was prepared freshly from egg yolks by the method of Pangborn (1951), except that the phospholipid was precipitated from the alcoholic extract with 10 vol. of cold acetone instead of $\mathrm{CdCl}_{2}$. Lecithin $(0.5 \% \mathrm{w} / \mathrm{v})$ and glycerol $(7.5 \% \mathrm{v} / \mathrm{v})$ were added to the sodium phosphate buffers. Egg yolk, buffered citrate and glycerol-fructose diluents were prepared as described by Blackshaw, Emmens, Martin \& Heyting (1957), with fructose replacing arabinose (Emmens \& Martin, 1961).

Semen was cold-shocked by plunging samples at $25^{\circ} \mathrm{C}$ into an ice-water mixture at $0^{\circ} \mathrm{C}$ and deep-frozen by placing them in finely crushed solid $\mathrm{CO}_{2}$. After $10 \mathrm{~min}$ all samples were thawed at $25^{\circ} \mathrm{C}$.

Analyses of variance were carried out on the data in Tables 1 and 2 with the sILLIAC digital computer. The interaction mean square has been used to calculate the standard errors (S.E.) of the differences between means as presented in these Tables, and has been used for the $t$-test. The standard errors of means in Table 3 are based on the original observations and a paired $t$-test was used.

\section{RESULTS}

GOMPARISON OF SPEGIES

\section{Bull and ram semen}

Experiments were begun with the semen of the bull and ram, species known to be particularly susceptible to cold shock. Neat semen and semen diluted $1: 4$ (bull) and $1: 8$ (ram) in sodium phosphate buffers were cold-shocked and 
deep-frozen. The concentration of sodium, potassium, calcium and magnesium in the spermatozoa was determined after thawing and compared with control samples kept at $25^{\circ} \mathrm{C}$. Cold-shocking and, to an even greater extent, deepfreezing, caused an increase in sodium and a decrease in the potassium and magnesium concentration of bull and ram spermatozoa (Table 1). The effects

TABLE 1

EFFEGT OF COLD-SHOCKING (C.S.) AND DEEP-FREEZING (D.F.) ON THE CONCENTRATION (mg/l00 $\mathrm{g}$ ) OF CATIONS IN SPERMATOZOA

\begin{tabular}{|c|c|c|c|c|c|c|}
\hline Species & Dilution & Treatment & Sodium & Potassium & Calcium & Magnesium \\
\hline \multirow[t]{3}{*}{$\begin{array}{l}\text { Bull } \\
\text { (4 replicates) }\end{array}$} & Nil & $\begin{array}{l}\text { Control } \\
\text { C.S. } \\
\text { D.F. }\end{array}$ & $\begin{array}{l}106 \\
136 \\
178 * *\end{array}$ & $\begin{array}{l}198 \\
163 * * \\
161 * *\end{array}$ & $\begin{array}{l}24 \cdot 8 \\
38 \cdot 0^{* *} \\
35 \cdot 7^{*}\end{array}$ & $\begin{array}{l}13 \cdot 3 \\
8 \cdot 7^{* *} \\
6 \cdot 8^{* *}\end{array}$ \\
\hline & $1: 4$ & $\begin{array}{l}\text { Control } \\
\text { C.S. } \\
\text { D.F. }\end{array}$ & $\begin{array}{l}152 \\
194 \\
203^{*}\end{array}$ & $\begin{array}{r}117 \\
76^{* *} \\
60^{* *}\end{array}$ & $\begin{array}{l}12 \cdot 4 \\
28 \cdot 0^{* *} \\
19 \cdot 7\end{array}$ & $\begin{array}{l}10 \cdot 7 \\
5 \cdot 6^{* *} \\
3 \cdot 6^{* *}\end{array}$ \\
\hline & & & S.E. $=18$ & S.E. $=5$ & S.E. $=3-2$ & S.E. $=1.5$ \\
\hline \multirow[t]{3}{*}{$\begin{array}{l}\text { Ram } \\
\text { (6 replicates) }\end{array}$} & Nil & $\begin{array}{l}\text { Control } \\
\text { C.S. } \\
\text { D.F. }\end{array}$ & $\begin{array}{l}139 \\
162 \\
176\end{array}$ & $\begin{array}{l}136 \\
95 * * \\
77^{* *}\end{array}$ & $\begin{array}{c}8 \cdot 0 \\
10 \cdot 8^{* *} \\
12 \cdot 6^{* *}\end{array}$ & $\begin{array}{c}13 \cdot 6 \\
9 \cdot 7^{*} \\
8 \cdot 8^{*}\end{array}$ \\
\hline & $1: 8$ & $\begin{array}{l}\text { Control } \\
\text { C.S. } \\
\text { D.F. }\end{array}$ & $\begin{array}{l}249 \\
326 * * \\
379 * *\end{array}$ & $\begin{array}{l}90 \\
31 * * \\
22 * *\end{array}$ & $\begin{array}{c}7 \cdot 8 \\
14 \cdot 6^{* *} \\
9 \cdot 4\end{array}$ & $\begin{array}{c}13 \cdot 5 \\
5 \cdot 0^{* *} \\
4 \cdot 3^{* *}\end{array}$ \\
\hline & & & S.E. $=20$ & S.E. $=5$ & S.E. $=0 \cdot 8$ & S.E. $=1.7$ \\
\hline \multirow[t]{2}{*}{$\begin{array}{l}\text { Dog } \\
\text { (4 replicates) }\end{array}$} & Nil & $\begin{array}{l}\text { Control } \\
\text { C.S. } \\
\text { D.F. }\end{array}$ & \begin{tabular}{|l|}
202 \\
184 \\
$417 *$
\end{tabular} & $\begin{array}{c}162 \\
186 \\
31^{* *}\end{array}$ & $\begin{array}{l}7 \cdot 1 \\
7 \cdot 4 \\
5 \cdot 5\end{array}$ & $\begin{array}{c}23 \cdot 0 \\
22 \cdot 7 \\
9 \cdot 0^{* *}\end{array}$ \\
\hline & & & S.E. $=66$ & S.E. $=18$ & S.E. $=1.5$ & S.E. $=3.0$ \\
\hline $\begin{array}{l}\text { Rabbit } \\
\text { (6 replicates) }\end{array}$ & Nil & $\begin{array}{l}\text { Control } \\
\text { C.S. } \\
\text { D.F. }\end{array}$ & $\begin{array}{c}128 \\
137 \\
151^{*} \\
\text { S.E. }=8 \\
\end{array}$ & $\begin{array}{c}119 \\
103^{*} \\
84^{* *} \\
\text { S.E. }=7 \\
\end{array}$ & $\begin{array}{c}63 \cdot 0 \\
65 \cdot 0 \\
78 \cdot 6^{*} \\
\text { S.E. }=6 \cdot 4 \\
\end{array}$ & $\begin{array}{c}41 \cdot 7 \\
46 \cdot 8 \\
50 \cdot 5 * * \\
\text { S.E. }=2 \cdot 5 \\
\end{array}$ \\
\hline \multirow[t]{2}{*}{$\begin{array}{l}\text { Man } \\
\text { (4 replicates) }\end{array}$} & Nil & $\begin{array}{l}\text { Control } \\
\text { C.S. } \\
\text { D.F. }\end{array}$ & $\begin{array}{l}228 \\
235 \\
257\end{array}$ & $\begin{array}{l}127 \\
127 \\
109\end{array}$ & $\begin{array}{l}30 \cdot 7 \\
32 \cdot 7 \\
31 \cdot 2\end{array}$ & $\begin{array}{r}11 \cdot 0 \\
8 \cdot 8 \\
10 \cdot 3\end{array}$ \\
\hline & & & S.E. $=39$ & S.E. $=24$ & S.E. $=6 \cdot 1$ & S.E. $=2 \cdot 5$ \\
\hline \multirow[t]{2}{*}{$\begin{array}{l}\text { Fowl } \\
\text { (6 replicates) }\end{array}$} & Nil & $\begin{array}{l}\text { Control } \\
\text { C.S. } \\
\text { D.F. }\end{array}$ & $\begin{array}{l}381 \\
479 \\
425\end{array}$ & $\begin{array}{r}107 \\
98 \\
88\end{array}$ & $\begin{array}{l}31 \cdot 7 \\
35 \cdot 6 \\
43 \cdot 3\end{array}$ & $\begin{array}{l}16 \cdot 7 \\
24 \cdot 1 \\
17 \cdot 1\end{array}$ \\
\hline & & & S.E. $=64$ & S.E. $=12$ & S.E. $=5 \cdot 7$ & S.E. $=3.9$ \\
\hline
\end{tabular}

$* P<0.05 ; * * P<0.01$ (significantly different from control).

in each instance were greater when the semen was diluted; dilution itself caused an efflux of potassium, calcium and magnesium from the spermatozoa and an influx of sodium. The calcium concentration of bull and ram spermatozoa rose after cold-shocking or deep-freezing; the highest rise was obtained after coldshocking the diluted samples.

Dog, rabbit, human and fowl semen

The effect of cold-shocking and deep-freezing the neat semen of the dog, rabbit, man and fowl (species not so susceptible to cold shock as the bull and 
ram) was next investigated and the concentration of the major cations in the spermatozoa are given in Table 1 .

In dog and rabbit spermatozoa, the sodium concentration increased and potassium decreased significantly on deep-freezing. However, with the exception of a slight fall in the potassium concentration of rabbit spermatozoa, there were no significant changes in the concentration of the major cations on cold-shocking. No statistically significant changes were observed in the cation concentration of human and fowl spermatozoa after either cold-shocking or deep-freezing.

\section{DEEP-FREEZING AFTER SLOW-COOLING TO $0^{\circ} \mathrm{C}$}

Ram semen was cooled slowly to $0^{\circ} \mathrm{C}$ to avoid cold-shocking and then deepfrozen to $-79^{\circ} \mathrm{C}$ or $-196^{\circ} \mathrm{C}$ (liquid nitrogen) and compared with similar samples frozen directly to these temperatures. The cation movements in and out of the spermatozoa were similar for both treatments at each temperature (i.e. an influx of sodium and calcium and an efflux of potassium and magnesium). The sodium concentration of the spermatozoa deep-frozen to $-196^{\circ} \mathrm{C}$ was higher than at $-79^{\circ} \mathrm{C}$, but there were no significant differences in the concentration of the other three cations.

\section{EFFECT OF LECITHIN AND GLYCEROL}

An experiment was designed to determine if the addition of $0.5 \%(\mathrm{w} / \mathrm{v})$ lecithin or $7.5 \%(\mathrm{v} / \mathrm{v})$ glycerol to sodium phosphate buffer would modify changes in the cation concentration of spermatozoa after cold-shocking and deep-freezing. Bull semen was diluted $1: 4$ and ram semen $1: 8$ and the results are presented in Table 2.

As in the first experiment, cold-shocking and deep-freezing caused a rise in the sodium and calcium concentration of the spermatozoa and falls in potassium and magnesium concentration. These changes were to some extent modified by lecithin and glycerol. Thus lecithin considerably depressed the rise in calcium and sodium found on cold-shocking bull and ram spermatozoa; glycerol had a similar effect with the bull, but not the ram. Neither lecithin nor glycerol had any beneficial effect in maintaining the cation status of the spermatozoa after deep-freezing and in fact lecithin rather exacerbated the rise in sodium.

It might be noted that glycerol itself, in these experiments, caused some disturbance of the cation status of bull and ram spermatozoa kept at room temperature for $10 \mathrm{~min}$. Thus, at the end of this period, potassium and magnesium levels were depressed and sodium and calcium levels increased.

\section{SEMEN DEEP-FROZEN UNDER OPTIMAL CONDITIONS}

Since the previous experiment did not demonstrate any beneficial effect of glycerol on the cation status of deep-frozen spermatozoa, when added to the diluent alone without any special processing, further tests were undertaken using semen deep-frozen under optimal conditions in glycerol-containing media.

The technique was essentially that described by Blackshaw et al. (1957). 
Semen was diluted with 2.5 vol. (bull) or 4.0 vol. (ram) of egg-yolk-citrate, and slowly cooled to $5^{\circ} \mathrm{C}$ over $2 \mathrm{hr}$. An equal volume of glycerol-fructose diluent at $5^{\circ} \mathrm{C}$ was added and equilibration continued for a further $2 \mathrm{hr}$ at $5^{\circ} \mathrm{C}$. The mixture was then deep-frozen in $1 \mathrm{ml}$ ampoules with apparatus to

TABLE 2

EFFECT OF LECITHIN AND GLYCEROL ON THE CONCENTRATION (mg/100 $\mathrm{g}$ ) OF MAJOR CATIONS IN SPERMATOZOA AFTER COLD SHOCK (C.S.) AND DEEP-FREEZING

(D.F.)

\begin{tabular}{|c|c|c|c|c|c|c|}
\hline Species & Treatment & Diluent & Sodium & Potassium & Calcium & Magnesium \\
\hline \multirow[t]{4}{*}{$\begin{array}{l}\text { Bull } \\
\text { (5 replicates } \\
1: 4 \text { dilution })\end{array}$} & Control & $\begin{array}{l}\text { Control } \\
\text { Lecithin } \\
\text { Glycerol }\end{array}$ & $\begin{array}{l}166 \\
163 \\
186^{*}\end{array}$ & $\begin{array}{l}167 \\
132 \\
149\end{array}$ & $\begin{array}{l}11 \cdot 7 \\
7 \cdot 9 \\
18 \cdot 2 * *\end{array}$ & $\begin{array}{l}12 \cdot 7 \\
10 \cdot 3^{*} \\
7 \cdot 9^{* *}\end{array}$ \\
\hline & C.S. & $\begin{array}{l}\text { Control } \\
\text { Lecithin } \\
\text { Glycerol }\end{array}$ & $\begin{array}{l}246 \\
209 * * \\
159 * *\end{array}$ & $\begin{array}{l}81 \\
66 \\
87\end{array}$ & $\begin{array}{l}29 \cdot 3 \\
16 \cdot 5 * * \\
13 \cdot 0^{* *}\end{array}$ & $\begin{array}{l}6 \cdot 0 \\
4 \cdot 7 \\
7 \cdot 7\end{array}$ \\
\hline & D.F. & $\begin{array}{l}\text { Control } \\
\text { Lecithin } \\
\text { Glycerol }\end{array}$ & $\begin{array}{l}242 \\
268 * * \\
236\end{array}$ & $\begin{array}{l}48 \\
53 \\
79\end{array}$ & \begin{tabular}{|l|}
$13 \cdot 3$ \\
$12 \cdot 3$ \\
$17 \cdot 1$
\end{tabular} & $\begin{array}{l}2 \cdot 7 \\
2 \cdot 7 \\
2 \cdot 5\end{array}$ \\
\hline & & & S.E. $=8$ & S.E. $=23$ & S.E. $=19$ & S.E. $=1.0$ \\
\hline \multirow[t]{4}{*}{$\begin{array}{l}\text { Ram } \\
\text { (4 replicates } \\
1: 8 \text { dilution) }\end{array}$} & Control & $\begin{array}{l}\text { Control } \\
\text { Lecithin } \\
\text { Glycerol }\end{array}$ & $\begin{array}{l}184 \\
194 \\
191\end{array}$ & $\begin{array}{l}102 \\
90 \\
65 * *\end{array}$ & $\begin{array}{r}8 \cdot 4 \\
7 \cdot 6 \\
11 \cdot 3\end{array}$ & $\begin{array}{r}11 \cdot 7 \\
11 \cdot 7 \\
9 \cdot 6\end{array}$ \\
\hline & C.S. & $\begin{array}{l}\text { Control } \\
\text { Lecithin } \\
\text { Glycerol }\end{array}$ & $\begin{array}{l}252 \\
229 \\
294\end{array}$ & $\begin{array}{l}56 \\
56 \\
61\end{array}$ & $\begin{array}{l}16 \cdot 5 \\
10 \cdot 8^{*} \\
16 \cdot 0\end{array}$ & $\begin{array}{l}9 \cdot 1 \\
7 \cdot 1 \\
8 \cdot 5\end{array}$ \\
\hline & D.F. & $\begin{array}{l}\text { Control } \\
\text { Lecithin } \\
\text { Glycerol }\end{array}$ & $\begin{array}{l}275 \\
302 \\
298\end{array}$ & $\begin{array}{l}28 \\
41 \\
27\end{array}$ & $\begin{array}{l}14 \cdot 2 \\
15 \cdot 2 \\
16 \cdot 6\end{array}$ & $\begin{array}{l}3 \cdot 6 \\
3 \cdot 7 \\
4 \cdot 2\end{array}$ \\
\hline & & & S.E. $=36$ & S.E. $=9$ & S.E. $=2 \cdot 1$ & S.E. $=1 \cdot 2$ \\
\hline
\end{tabular}

${ }^{*} P<0.05 ;{ }^{* *} P<0.01$ (significantly different from the control).

TABLE 3

EFFECT OF EGG-YOLK-CITRATE/GLYCEROL-FRUCTOSE DILUENT ON THE SODIUM AND POTASSIUM CONCENTRATION OF DEEP-FROZEN SPERMATOZOA

\begin{tabular}{c|l|c|c}
\hline Species & \multicolumn{1}{|c|}{ Treatment } & \multicolumn{1}{|c|}{ Sodium } & Potassium \\
\hline Bull & Control & $552 \pm 29 \cdot 6$ & $36 \pm 1 \cdot 7$ \\
& Egg-yolk-citrate/glycerol-fructose & $387 \pm 26 \cdot 8^{*}$ & $101 \pm 9 \cdot 4^{* *}$ \\
Ram & Control & $480 \pm 21 \cdot 1$ & $9 \pm 3 \cdot 3$ \\
& Egg-yolk-citrate/glycerol-fructose & $348 \pm 11 \cdot 8^{* *}$ & $65 \pm 8 \cdot 7^{* *}$ \\
\hline
\end{tabular}

Mean values $(\mathrm{mg} / 100 \mathrm{~g}) \pm$ S.E. are given for five replications on each species. ${ }^{*} P<0.05 ; * * P<0.01$.

give a cooling rate of less than $2^{\circ} \mathrm{C} / \mathrm{min}$, the whole procedure down to $-79^{\circ} \mathrm{C}$ taking about $2 \mathrm{hr}$. In the controls, buffered sodium citrate replaced the eggyolk and glycerol-fructose solutions at the appropriate stages in the freezing procedure.

Sodium and potassium estimations were made on the spermatozoa after rapid thawing in a water-bath at $37^{\circ} \mathrm{C}$ and the results are presented in Table 3. Spermatozoa frozen in the egg-yolk/glycerol-fructose mixture had a significantly 
lower sodium and a higher potassium concentration than control samples frozen in a medium which did not contain these protective agents.

\section{DISGUSSION}

These experiments clearly establish that, when bull and ram semen is coldshocked, sodium and calcium accumulate in the spermatozoa and potassium and magnesium are lost. This conclusion, based on direct analyses of the spermatozoa, is substantiated by the work of Blackshaw \& Salisbury (1957), who measured the sodium, potassium and calcium content of seminal plasma before and after cold-shocking bull semen. The movement of cations is not as great when human, dog, rabbit or fowl spermatozoa are cold-shocked, which is of interest since the spermatozoa of these species are not so susceptible to cold shock as judged by motility and vital staining techniques (White \& Wales, 1959; Wales \& White, 1959).

Deep-freezing produced a similar, but more severe, disturbance of the cation movements and significant effects were seen with the spermatozoa of all species, except the fowl and human. It may be noted that human spermatozoa have long been known to survive deep-freezing moderately well in tubes or ampoules without adding glycerol to the medium (Davenport, 1897; Jahnel, 1938; Shettles, 1940; Parkes, 1945; Emmens \& Blackshaw, 1950).

The cation movements caused by cooling ram spermatozoa from $0^{\circ} \mathrm{C}$ to $-79^{\circ} \mathrm{C}$ are greater than those resulting from rapidly cooling from room temperature to $0^{\circ} \mathrm{C}$, so that substantially similar results occur on deep-freezing spermatozoa, whether or not precautions have been taken to cool the semen slowly to $0^{\circ} \mathrm{C}$. The possibility of cold-shocking below $0^{\circ} \mathrm{C}$ has been reported by Lovelock \& Polge (1954). Further changes in spermatozoa must occur between $-79^{\circ} \mathrm{C}$ and $-196^{\circ} \mathrm{C}$ to account for the increase in the sodium concentration of the spermatozoa between these temperatures.

Diluting bull and ram semen accentuated the cation movements of both cold-shocked and deep-frozen spermatozoa, which is consistent with the motility observations of Choong \& Wales (1962) on bull semen. The pronounced exchange of cations induced by dilution has been previously investigated and discussed (Quinn, White \& Wirrick, 1966).

The potassium and magnesium concentration in bull and ram spermatozoa is greater than in the seminal plasma and the sodium concentration in the seminal plasma exceeds that of the spermatozoa (Cragle, Salisbury \& Muntz, 1958; Quinn et al., 1965). The movement of all three ions on cold-shocking and deep-freezing is therefore in the direction of the concentration gradient. This is also true for the movement of calcium into bull spermatozoa on coldshocking and deep-freezing, since the calcium concentration of the seminal plasma in this species exceeds that of the spermatozoa (Cragle et al., 1958; Quinn et al., 1965). The accumulation of calcium on cold-shocking neat or diluted ram spermatozoa or diluted bull spermatozoa must, however, be against a concentration gradient. Merely diluting bull and ram spermatozoa causes an efflux of calcium at $25^{\circ} \mathrm{C}$ (Table 1 ; see also Quinn et al., 1966), and calcium must be actively accumulated specifically on cold-shocking. There is, however, 
no increase after deep-freezing when, due possibly to gross damage to the cell membrane, a state of equilibrium or near equilibrium has been reached between spermatozoa and seminal plasma.

Beljkevic, Kljucareva, Rombe \& Filaretova (1959) have postulated that calcium is released from the external lipoprotein layer of spermatozoa on coldshocking and passes into the cell, causing disorganization of the protoplasm and inhibition of enzyme systems. They also suggest that the protective action of various substances (e.g. lecithin, casein and ethylenediaminetetracetic acid) against cold shock is due to their ability to bind the released calcium and to prevent it passing into the spermatozoa. Whilst our experiments do not provide any evidence for the translocation of calcium within the spermatozoa on coldshocking they do suggest that it actively accumulates. Furthermore, the accumulation of calcium by cold-shocked bull and ram spermatozoa is largely prevented by lecithin and glycerol, and the protective effect of these and other substances in relation to calcium warrants further investigation.

Blackshaw (1958) has reported that lecithin does not prevent a decline in the glycolysis of ram spermatozoa after cold-shocking as effectively as was found by Blackshaw \& Salisbury (1957) in the bull. However, half the lecithin concentration used by these workers was as effective in decreasing calcium accumulation in ram as in bull spermatozoa.

The rapid addition of glycerol to semen is, in itself, likely to produce disturbances of the cation concentration in spermatozoa similar to the more drastic changes that follow deep-freezing. Table 3, however, shows that the influx of sodium into bull and ram spermatozoa and the loss of potassium can be greatly reduced if the semen is deep-frozen under optimal conditions in a glycerol-containing medium. Further experiments are necessary to determine whether the equilibration or ageing process investigated by Martin (1963) is important in this respect or whether one of the constituents of the diluent (e.g. egg yolk, citrate or fructose) has a major role to play in maintaining the cation status of spermatozoa deep-frozen under these conditions.

\section{ACKNOWLEDGMENTS}

The authors are indebted to Professor C. W. Emmens for his interest and advice; to Dr I. C. A. Martin for his assistance with deep-freezing semen and to $\mathrm{Mr}$ B. R. Wirrick for his collaboration in some of this work. We are also grateful to Dr H. W. McNary of the Poultry Research Unit, Camden, for the supply of fowl semen and to the Sterility Clinic of the Women's Hospital, Crown Street, Sydney, for human semen. The work has been aided by grants from the Ford Foundation, the Rural Credits Development Fund of the Commonwealth Bank of Australia, the Australian Wool Board, the Australian Dairy Produce Board and the Australian Cattle \& Beef Research Committee.

\section{REFERENCES}

Beljkevic, V. I., Kljucareva, Z. S., Rombe, S. M. \& Filaretova, N. V. (1959) Protection of bull spermatozoa from cold shock. (Translated title). Trudỹ vses. nauchno-issled. Inst. Zhivot. 23, 211.

Blackshaw, A. W. (1954) The prevention of temperature shock of bull and ram semen. Aust. F. biol. Sci. 7, 573 . 
Blackshaw, A. W. (1958) The effects of incubation temperature and cold shock on the metabolism of ram spermatozoa. Aust. 7. biol. Sci. 11, 581.

Blackshaw, A. W., Emmens, C. W., Martin, I. \& Heyting, J. (1957) The preparation of deep frozen semen. A.I. Dig. 5, 6.

Blackshaw, A. W. \& Salisbury, G. W. (1957) Factors influencing metabolic activity of bull spermatozoa. 11. Cold shock and its prevention. 7. Dairy Sci. 40, 1099.

Choong, C. H. \& Wales, R. G. (1962) The effect of cold shock on spermatozoa. Aust. 7. biol. Sci. 15, 543.

Cragle, R. G., Salisbury, G. W. \& Muntz, T. H. (1958) Distribution of bulk and trace metals in bull reproductive tract fluids and semen. 7 . Dairy Sci. 41, 1273.

DAVENPORT, C. B. (1897) Experimental Morphology. I. Effect of chemical and physical agents upon protoplasm. Macmillan, New York.

Emmens, C. W. \& Blackshaw, A. W. (1950) Low temperature storage of ram, bull and rabbit spermatozoa. Aust. vet. F. 26, 226.

Emmens, C. W. \& Blackshaw, A. W. (1956) Artificial insemination. Physiol. Rev. 36, 277.

Emmens, C. W. \& Martin, I. C. A. (1961) The effects of equilibration period and sugar content of the diluent on the survival and fertility of bull spermatozoa deep-frozen to $-79^{\circ} \mathrm{C}$. Proc. 4 th int. Congr. Anim. Reprod., The Hague, p. 964.

Hancock, J. L. (1951) A staining technique for the study of temperature shock in semen. Nature, Lond. $167,323$.

JAHNEL, F. (1938) Uber die Widerstandsfahigkeit von menschlichen Spermatozoen gegenuber starker Kalte. Wiederauftreteter der Beweglichkeit nach Abkuhlung auf $-196^{\circ} \mathrm{C}$ (flussiger Stickstoff) und $-269.5^{\circ} \mathrm{C}$ etwa $3.7^{\circ}$ vom absoluten Nullpunkt entfernt (flussiges Helium). Klin. Wschr. $17,1273$.

Kampschmidt, R. F., Mayer, D. T. \& Herman, H. A. (1953) Viability of bull spermatozoa as influenced by various sugars and electrolytes in the storage medium. Res. Bull. Mo. agric. Exp. Stn. No. 519 .

Lasley, J. F., Easley, G. T. \& McKenzie, F. F. (1942) A staining method for the differentiation of live and dead spermatozoa. I. Applicability to the staining of ram spermatozoa. Anat. Rec. 82, 167.

Lovelock, J. E. \& Polge, C. (1954) The immobilisation of spermatozoa by freezing and thawing and the protective action of glycerol. Biochem. 7. 58, 618 .

MANN, T. \& LUTWAK-MANN, C. (1955) Biochemical changes underlying the phenomenon of cold shock in spermatozoa. Archs Sci. biol. 39, 578.

Martin, I. C. A. (1963) Revival of bull spermatozoa after deep freezing to $-79^{\circ} \mathrm{C}$ following equilibration in diluents of various tonicities. 7. Reprod. Fert. 6, 433.

MAule, J. P. (Ed.) (1962) The semen of animals and artificial insemination. Techn. Commun. No. 15, Commonw. Bur. Anim. Breed. Genet., Edinburgh.

Pangborn, M. C. (1951) A simplified purification of lecithin. F. biol. Chem. 188, 471.

Parkes, A. S. (1945) Preservation of human spermatozoa at low temperature. Brit. med. 7. ii, 212.

Polge, C., Sмith, A. U. \& Parkes, A. S. (1949) Revival of spermatozoa after vitrification and dehydration at low temperatures. Nature, Lond. 164, 666.

QuinN, P. J., WhITE, I. G. \& WIRRICK, B. R. (1965) Studies of the distribution of the major cations in semen and male accessory secretions. $\mathcal{F}$. Reprod. Fert. 10, 379.

Quinn, P. J., WhITE, I. G. \& WIRRICK, B. R. (1966) The effect of dilution on the concentration of sodium, potassium, calcium and magnesium in ram and bull spermatozoa. F. Reprod. Fert. 12, 133.

Shettres, L. B. (1940) The respiration of human spermatozoa and their responses to various gases and low temperatures. Am. F. Physiol. 128, 408.

SмIth, A. U. \& Polge, C. (1950a) Storage of bull spermatozoa at low temperatures. Vet. Rec. 62, 115.

Smith, A. U. \& Polge, G. (1950b) Survival of bull spermatozoa at low temperatures. Nature, Lond. $166,668$.

Wales, R. G. \& White, I. G. (1959) The susceptibility of spermatozoa to temperature shock. $\mathcal{J}$. Endocr. 19, 211.

Walton, A. (1957) Cold shock of spermatozoa. Proc. R. Soc. B, 147, 508.

White, I. G., Blackshaw, A. W. \& Emmens, C. W. (1954) Metabolic and motility studies relating to the low temperature storage of ram and bull spermatozoa. Aust. vet. J. 30, 85.

White, I. G. \& Wales, R. G. (1959) The susceptibility of spermatozoa to cold shock. Int. F. Fert. 5, 195. 